University of Pennsylvania Carey Law School

Penn Law: Legal Scholarship Repository

Faculty Scholarship at Penn Law

$12-17-2012$

\title{
Comparative Antitrust Federalism: Review of Cengiz, Antitrust Federalism in the EU and the US
}

Herbert J. Hovenkamp

University of Pennsylvania Carey Law School

Follow this and additional works at: https://scholarship.law.upenn.edu/faculty_scholarship

Part of the Antitrust and Trade Regulation Commons, Comparative and Foreign Law Commons, Comparative Politics Commons, Economic Policy Commons, European Law Commons, Industrial Organization Commons, and the Law and Economics Commons

\section{Repository Citation}

Hovenkamp, Herbert J., "Comparative Antitrust Federalism: Review of Cengiz, Antitrust Federalism in the EU and the US" (2012). Faculty Scholarship at Penn Law. 1907.

https://scholarship.law.upenn.edu/faculty_scholarship/1907

This Article is brought to you for free and open access by Penn Law: Legal Scholarship Repository. It has been accepted for inclusion in Faculty Scholarship at Penn Law by an authorized administrator of Penn Law: Legal Scholarship Repository. For more information, please contact PennlawIR@law.upenn.edu. 


\section{Cengiz, Comparative Antitrust Federalism}

\section{COMPARATIVE ANTITRUST FEDERALISM: Review of Cengiz, Antitrust Federalism in the EU AND the US ${ }^{1}$}

This well written, short book compares the role of federalism in the competition law of the European Union and the United States. Both of these systems are "federal," of course, because both have individual nation-states (Europe) or states (US) with their own individual competition provisions, but also an overarching competition law that applies to the entire group. This entails that a certain amount of cooperation is necessary with respect to both territorial reach and substantive coverage.

Cengiz book reaches significantly beyond legal analysis to examine the economics of federalism and also the political processes that characterize competition policy federalism in the EU and the US. As Cengiz observes, multi-level political regimes present a form of diversity that "stands both as an advantage and a disadvantage" for good governance. On the one hand, this type of diversity contributes to innovation, flexibility and responsiveness; on the other, it can jeopardize consistency and increase both enforcement costs and compliance costs. (p. 1). After presenting basic issues and a framework for analysis in Chapter 1, Chapter 2 develops two alternative models of federalism. The first one is "regulatory competition," which treats federalist systems as laboratories in which differing ideas can be tried out and tested against each other. The second is a model of "policy networks" which emphasizes cooperation rather than competition among the different governments in a federal system.

\footnotetext{
${ }^{1}$ Firat Cengiz, Antitrust Federalism in the EU and the US. London \& New York: Routledge, 2012. isbn: 978-0-415-67463. 234 pages inc. index.
} 


\section{Cengiz, Comparative Antitrust Federalism}

Cengiz distinguishes among "markets," "hierarchies," and "networks" as forms of federalism. Markets are the least centralized and have more episodic, or ad hoc, control. As a result they are more prone to policy "races." A "race to the bottom" occurs when the smaller sovereigns compete in a larger market and attempt to reduce costs in a way that would be suboptimal if it were forced to internalize all relevant costs. She offers as an example United States corporate law, in which state chartering provides the legal corporate governance framework, even for companies that operate nationally or internationally. As a result they might race with each other to provide less supervision or rules that give greater discretion to management then would be optimal if all of the relevant stakeholders were located within the sovereign's own boundaries. This might happen, for example, when shareholders are dispersed much more widely than the jurisdiction creating the corporate law mechanism. One result of this race in the United States was that Delaware, a rather small state, has succeeded in claiming an unduly large share of the charters of multistate and multinational corporations. Whether this has truly been a "race to the bottom" is debatable, however. Others have argued that the race that allegedly characterized Delaware corporate law was in reality a race to the top, which Delaware won by providing the most efficient structures for corporate governance. Cengiz argues that legal policy can in fact be structured in ways to ensure that the "races" that occur among sovereigns in a federal setting are in fact races to the top rather than races to the bottom.

Cengiz concludes that the EU and US systems are similar in that both begin with a set of system-wide policies that are broad and strong, with internal unification as a primary objective. Where they tend to differ is in areas governing conflicts between the laws at the different levels. Here, the US system is more structured and hierarchical, while the EU system tends to rely more 


\section{Cengiz, Comparative Antitrust Federalism}

on cooperation. Cengiz describes the US as emerging from "bottom up collective action," while that in the EU is more cooperative. At the same time, however, within the US all of the individual antitrust authorities are thought of as enjoying equal authority throughout their respective domains, while the central authority in the EU operates more as a network manager.

Cengiz ultimately finds the regulatory competition model to be inferior to the network model of federalism. The regulatory competition model most generally evaluates policies of individual states by permitting people to vote with their feet. She concludes that the regulatory competition model does not provide a "suitable template" for competition policy, mainly because of the impact of spillovers and also its competitive nature. Such systems are more prone to "overcrowding," in the sense of inconsistency or unnecessary complexity in compliance with the commands of differing sovereigns. In contrast to the market-based competitive approach, network approaches toward federalism tend to be more stable and to provide fewer opportunities for conflict. At the same time, however, networks are "at least theoretically prone to conflicts and deadlocks" as well. (p. 37). They are crucially dependent on the continuous exchange and updating of information, while competitive federalism actually produces motives for individual sovereigns to withhold information from one another, or at least to go it alone without making engagement with other portions of the system an essential attribute of enforcement decisions.

Cengiz also finds differing approaches to network federalism within the EU, and in particular distinguishes British, German and Dutch approaches. The British use an "Interest intermediation" approach, the Germans a "Governance" approach, and the Dutch a "public management" approach. [p. 41] 


\section{Cengiz, Comparative Antitrust Federalism}

In general, it seems, the European approach to federalism reflects a more managerial, or regulatory, conception of competition policy, in distinction from the more market driven selective interventionist approach that characterizes the American system. The American approach to federalism is more consistent with market-driven systems generally, in which the sovereign intervenes only selectively and less day-to-day cooperation is required. As Cengiz observes, "From a general perspective, regulatory competition as a model does not reflect the complexities of modern multi-level polities," but is more likely to reflect individual policies and subsequent efforts to harmonize them. As a result, competitive networks are more likely to become subject to excessive, overlapping or sometimes conflicting regulations. Another problem she observes and that those of us in the United States understand all too well is that the division between federal and state regulatory power contemplated in the United States Constitution, a 225 year old document that did not have modern competition policy in mind, is both too complex and too ambiguous. The line between federal power to regulate under the Commerce Clause and limitations on state power under the "dormant" Commerce Clause remains elusive, is constantly changing, and its location is often driven more by ideology than sound economic reasoning.

One additional idiosyncrasy of American antitrust federalism is the expansive set of private rights created by United States law as well as the antitrust law of most states. Some ninety percent of antitrust actions in the United States are filed by private persons, and historically they have not effected any coherent policy. While many of these cases follow after government enforcement actions, such as price-fixing conspiracies, many others do not. Further, some of them proceed under both federal and state law in substantive areas that the federal 


\section{Cengiz, Comparative Antitrust Federalism}

government has largely abandoned, such as price discrimination or resale price maintenance. Otherwise they take advantage of state statutes that are substantively quite different from federal law, such as state provisions prohibiting noncompetition agreements or 'below cost' pricing but defining cost and illegality in ways that are very different than federal law defines them.

Cengiz concludes by finding some similarity but also important differences between EU and US antitrust. For example, "in contrast to the deferential application of preemption doctrine to conflict of antitrust in the US, in the EU the strict principles of primacy prevents experimentations in competition policy at the national level." In this reviewer's opinion that statement contains a great deal of truth. In the United States intervention tends to be episodic and sometimes unexpected. Particularly with respect to government enforcement, intervention only occurs after a practice has been going on for some time.

Apropos of this, United States antitrust federalism is subject to a highly complicating factor -- namely, the state action "exemption," which gives states virtual carte blanche to regulate activity within their boundaries (and even a certain amount outside of their boundaries), provided that they have articulated their desire to do so and that they actively supervise any private conduct that the regulatory regime authorizes. In a very few situations, such as professional sports, the courts have found an overriding need for uniformity that preempts individual state prerogatives. Aside from these situations, however, the state power is broad, limited mainly by preemptive federal regulation aside from the antitrust laws, such as federal policy regarding intellectual property rights, labor, securities, civil rights, or environmental protection. For example, state law in the United States has the power to immunize 


\section{Cengiz, Comparative Antitrust Federalism}

anticompetitive mergers, even mergers to monopoly, if the state has clearly articulated this policy as its goal. Federal antitrust law also routinely approves monopoly franchises to companies in competitively structured industries, such as taxicab transportation or waste disposal, in which competition is clearly in consumers' interest.

This is an excellent book, of interest to academicians or legislators as much as practicing lawyers in areas of federal regulatory conflict.

Herbert Hovenkamp

May 2012

Iowa City Iowa 